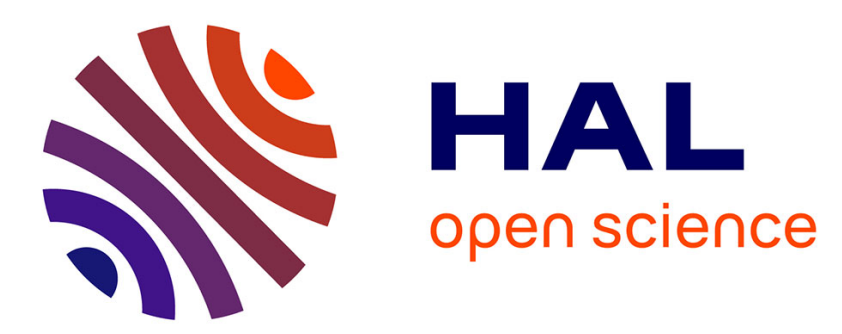

\title{
Further studies on the human pancreatic binary complexes involving procarboxypeptidase A
}

M. Moulard, Thierry Michon, Brigitte Kerfelec, Catherine Chapus

\section{To cite this version:}

M. Moulard, Thierry Michon, Brigitte Kerfelec, Catherine Chapus. Further studies on the human pancreatic binary complexes involving procarboxypeptidase A. FEBS Letters, 1990, 261 (1), pp.179183. hal-02709529

\author{
HAL Id: hal-02709529 \\ https://hal.inrae.fr/hal-02709529
}

Submitted on 1 Jun 2020

HAL is a multi-disciplinary open access archive for the deposit and dissemination of scientific research documents, whether they are published or not. The documents may come from teaching and research institutions in France or abroad, or from public or private research centers.
L'archive ouverte pluridisciplinaire HAL, est destinée au dépôt et à la diffusion de documents scientifiques de niveau recherche, publiés ou non, émanant des établissements d'enseignement et de recherche français ou étrangers, des laboratoires publics ou privés. 


\title{
Further studies on the human pancreatic binary complexes involving procarboxypeptidase A
}

\author{
Maxime Moulard, Thierry Michon*, Brigitte Kerfelec and Catherine Chapus \\ Centre de Biochimie et de Biologie Moléculaire du CNRS, 31 Chemin Joseph Aiguier, 13402 Marseille Cedex 9, France and \\ *Laboratoire de Biochimie et Technologie des Protéines I.N.R.A., Rue de la Géraudière, 44026 Nantes Cedex 03, France
}

Received 1 December 1989

In contrast to procarboxypeptidase B which has always been reported to be secreted by the pancreas as a monomer, procarboxypeptidase $\mathrm{A}$ occurs as a monomer and/or associated to one or two functionally different proteins, depending on the species. Recent studies showed that, in the human pancreatic secretion, procarboxypeptidase $\mathrm{A}$ is mainly secreted as a $44 \mathrm{kDa}$ protein involved in at least three different binary complexes. As previously reported, two of these complexes associated procarboxypeptidase A to either a glycosylated truncated protease $\mathrm{E}$ or zymogen $\mathrm{E}$. In this paper, we identified proelastase 2 as the partner of procarboxypeptidase $A$ in the third complex. thus reporting for the first time the occurrence of a proelastase 2/procarboxypeptidase A binary complex in vertebrates. Moreover. from $\mathrm{N}$-terminal sequence analyses, the $44 \mathrm{kDa}$ procarboxypeptidase $\mathrm{A}$ involved in these complexes was identified as being of the $A_{1}$ type. Only one type of procarboxypeptidase $B$, the $B_{1}$ type, has been detected in the analyzed pancreatic juices. thus emphasizing the previously observed genetic differences between individuals.

Human pancreas: Procarboxypeptidase: Protease E; Proelastase 2: Protein complex

\section{INTRODUCTION}

Various molecular forms of secreted proCPA, resulting from its ability to bind to other pancreatic serine endopeptidases, have been reported. In some ruminant species, proCPA is secreted as a ternary complex $[1,2]$ in association with a chymotrypsinogen of the C-type [3] and a truncated protease E [4,5]. Binary complexes in which proCPA is associated to either probably a chymotrypsinogen of the C-type or to zymogen $E$ have been described in the sei whale [6] and in the pig [7], respectively. In the human secretion, two major binary complexes in which proCPA is associated to either a glycosylated truncated protease $\mathrm{E}(32 \mathrm{kDa})$ or an unidentified $28 \mathrm{kDa}$ protein have been reported [8]. A binary form in which proCPA is bound to zymogen $\mathrm{E}$ has also been described in human pancreas [9]. On the other hand, in several species such as dog [10], dogfish [11], lungfish [12] and horse [2], proCPA is secreted as a monomer. However, in some species,

Correspondence address: C. Chapus, Centre de Biochimie et de Biologie Moleculaire du CNRS, 31 Chemin Joseph Aiguier, 13402 Marseille Cedex 9, France

Abbreviations: DMMA, 2,3 dimethylmaleic anhydride; t-Boc Ala $N$ t-Boc-L-alanine $p$-nitrophenyl ester; HPLA, hippuryl-L- phenyllactic acid and $H A$, hippuryl-L-arginine; ProCPA, procarboxypeptidase $A$; proCPB, procarboxypeptidase B; CPA, carboxypeptidase A; CPB, carboxypeptidase $\mathrm{B}$

Enzymes: (pro)carboxypeptidase A (EC 3.4.17.1); (pro)carboxypeptidase B (EC 3.4.17.2); pro(elastase), (zymogen E) protease E (EC 3.4.21.36); trypsin (EC 3.4.21.4)
proCPA is secreted in two states. Thus, besides the above-mentioned binary forms, the porcine [7] and human [9] secretions contain monomeric proCPA.

Besides this heterogeneity of molecular forms of secretion, two types of proCPA ( $\mathbf{A}_{1}$ and $\left.\mathbf{A}_{2}\right)$, differing by their substrate specificities and primary sequences and resulting from gene duplication, allelic polymorphism and/or differential processing of the mature enzyme have been reported in man [13] and rat [14]. Two types of proCPB $\left(B_{1}\right.$ and $\left.B_{2}\right)$ have also been reported in man [13].

In this paper, we report that in the human pancreatic juices investigated, the $28 \mathrm{kDa}$ protein associated to proCPA is a proelastase 2. Moreover, from N-terminal sequence analyses, the human $44 \mathrm{kDa}$ procPA of the two binary complexes was shown to belong to the $A_{1}$ type and the proCPB to the $B_{1}$ type.

\section{MATERIALS AND METHODS}

\subsection{Materials}

Lyophilized pancreatic juices devoid of any proteolytic activity were a generous gift from Dr Lombardo (CBBM, CNRS. Marseille). DMMA and t-Boc Ala ONp were purchased from Sigma (St Louis, MO, USA). HPLA and HA were from Bachem (Budendorf, Switzerland). Benzamidine was from Fluka (Zurich. Switzerland). All chemicals used in this study were of analytical grade and were used without further purification. Ultrogel AcA 54 and DE-Trisacryl were from IBF (Villeneuve-la-Garenne, France) and Superose 12 from Pharmacia (Uppsala, Sweden).

\subsection{Methods}

2.2.1. Filtration of lyophylized human pancreatic juice on AcA 54 Ultrogel 
This filtration was performed as reported in [8].

\subsubsection{Activity measurements}

CPA activity was potentiometrically measured after tryptic activation as previously reported [15] using a $1 \mathrm{mM}$ HPLA solution as substrate. In order to avoid the inhibitory effect of the activation peptide, monomeric proCPA was first acylated by DMMA before tryptic activation [15]. The CPB activity was determined spectrophotometrically after tryptic activation using a $1 \mathrm{mM}$ HA solution according to [16]. The protease $E$ and elastase 2 activities were determined porentiometrically at $\mathrm{pH} 7.5$ and $25^{\circ} \mathrm{C}$ using a $10 \mathrm{mM} \mathrm{N}$-acetyl L-tyrosine ethyl ester solution as substrate in a $1 \mathrm{mM}$ Tris- $\mathrm{HCl}$ buffer containing $0.1 \mathrm{M} \mathrm{NaCl}$. Spectrophotometric assays for protease $\mathrm{E}$ and elastase 2 activities were also performed at $\mathrm{pH} 6.0$ and $25^{\circ} \mathrm{C}$ using $0.8 \mathrm{mM}$ t-Boc Ala ONp as substrate according to [17].

\subsubsection{Purification and dissociation of the binary complexes}

The fractions containing the binary complexes eluted from the above-mentioned gel filtration column were purified as reported [8]. The dissociation of the two binary complexes was performed by treatment with DMMA as previously reported [18]. The free dimethylmaleylated subunits of the complexes were then separated by molecular sieving on an AcA Uitrogel 54 Ultrogel $(1 \mathrm{~cm} \times 4 \mathrm{~m})$ or on a Superose 12 column using a Fast Protein Liquid Chromatograph (Pharmacia). The columns were equilibrated and eluted with a $0.1 \mathrm{M}$ sodium bicarbonate buffer, $\mathrm{pH} \cdot 9.0$, containing $0.4 \mathrm{M} \mathrm{NaCl}$ and $1 \mathrm{mM}$ benzamidine. Deacylation of the subunits was obtained by dialysis at $4^{\circ} \mathrm{C}$ for $48 \mathrm{~h}$ at $\mathrm{pH} 7.0$ for proCPA and for $24 \mathrm{~h}$ at $\mathrm{pH} 6.0$ for the other two proteins.

\subsubsection{Purification of monomeric procarboxypeptidase $B$}

The fractions containing proCPB resulting from AcA 54 gel filtration of lyophilized human pancreatic juice were pooled, extensively dialyzed against a $20 \mathrm{mM}$ Tris- $\mathrm{HCl}$ buffer, $\mathrm{pH} 8.0$, containing $50 \mathrm{mM}$ $\mathrm{NaCl}$ and $1 \mathrm{mM}$ benzamidine, and then chromatographed on a DETrisacryl column $(2 \times 15 \mathrm{~cm})$ equilibrated in the same buffer. The elution was performed using the same buffer. CPA and CPB activities were tested as reported above, all along the elution profile.

\subsubsection{Gel electrophoresis}

Electrophoresis in the presence of SDS was carried out in 10-15\% polyacrylamide gel as described by Laemmli [19] using a Phast gel ap- paratus (Pharmacia). The proteins were stained with $0.25 \%$ Coomassie brilliant blue and destained in acetic acid/ethanol/water mixtures $(1.5: 1.0: 17.5, \mathrm{v} / \mathrm{v})$.

\subsubsection{N-terminal sequence analyses}

$\mathrm{N}$-terminal sequence analyses were performed by stepwise Edman degradation using a gas phase sequencer (Applied Biosystems, model 470A). The resulting phenylthiohydantoins were analyzed by HPLC using a $\mathrm{C}_{18}$ column (Brownlee, $5 \mathrm{~mm}, 2.1 \times 220 \mathrm{~mm}$ ). They were eluted by a methanol gradient $(10-46 \%)$ in a $5 \mathrm{mM}$ sodium acetate buffer, $\mathrm{pH} 4.84$.

\section{RESULTS}

\subsection{Purification and characterization of the two binary complexes}

The two major binary complexes, isolated from gel filtration of human pancreatic juice were further purified to homogeneity by chromatography on DETrisacryl as reported [8], and then dissociated using the DMMA method elaborated for the dissociation of the bovine proCPA-S6 ternary complex [18]. The complete separation of the free acylated partners (proCPA, 32 and $28 \mathrm{kDa}$ proteins) was achieved by molecular sieving on AcA 54 Ultrogel or Superose 12 at pH 9.0. For each binary complex, two well-separated peaks were obtained and the proteins were deacylated as described in section 2. The deacylated protein solutions were found homogeneous by SDS gel analysis and investigated without further purification.

As previously reported [8], the $32 \mathrm{kDa}$ protein associated to the $44 \mathrm{kDa}$ proCPA in the first complex was devoid of any activity towards specific substrates. This glycoprotein was unambiguously identified to a truncated protease $\mathrm{E}$.

Table 1

Comparison of $\mathrm{N}$-terminal sequences of proCPA from various species

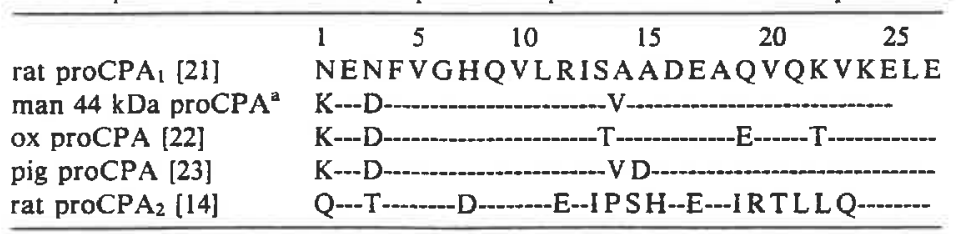

${ }^{2} 44 \mathrm{kDa}$ proCPA from the two human binary complexes (proCPA / truncated protease $E$ and proCPA / proelastase 2). The rat proCPA, sequence is used as reference

Table 2

Comparison of the N-terminal sequences of the CPA from different species

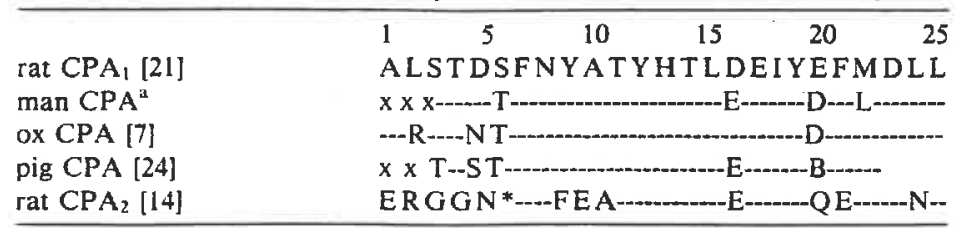

${ }^{\text {a }} \mathrm{CPA}$ resulting from tryptic activation of proCPA/proelastase 2 binary complex. The rat CPA is used as reference. Deletions $\left(^{*}\right)$ have been inserted in order to optimize sequence alignment. $x$, unidentified residues 


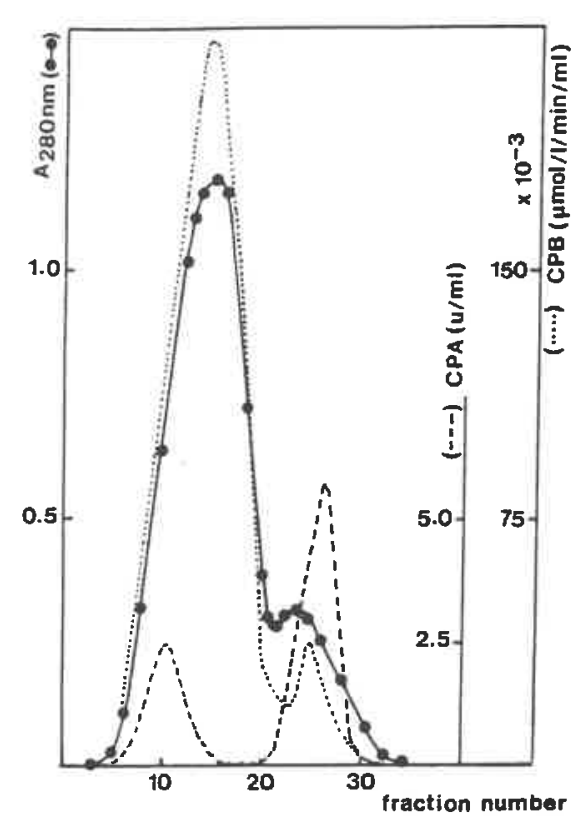

Fig.1. DE-Trisacryl chromatography of monomeric procarboxypeptidases. The monomeric procarboxypeptidases were purified on a DETrisacryl column as indicated in section 2 . Flow rate, $35 \mathrm{ml} / \mathrm{h}$; fraction volume, $3.5 \mathrm{ml}$. Carboxypeptidase A (---) and B (....) potential activities were determined as described (see section 2) after tryptic activation.

The isolated $28 \mathrm{kDa}$ protein was found inactive towards the various serine endopeptidase substrates. However, after incubation with catalytic amounts of trypsin, the protein displayed an activity towards both $N$-acetyl L-tyrosine ethyl ester and t-boc Ala ONp compatible with an elastase 2 specificity. In order to further identify this $28 \mathrm{kDa}$ protein, the $\mathrm{N}$-terminal sequence of the trypsin activated form has been carried out. The following sequence, extending to residue 34 , was obtained:

\section{$\begin{array}{lllllll}1 & 5 & 10 & 15 & 20 & 25 & 30\end{array}$ \\ XGDPTYPPYVTRVVGGEEARPNSWPWQVSLQYSS}

Except for the first amino acid which has not been identified $(\mathrm{X})$, this sequence is identical to that of the corresponding sequence of human proelastase 2 deduced from cDNA sequencing by Shirasu et al. [20]. This finding confirms the activity studies and allows us to unambiguously identify the $28 \mathrm{kDa}$ protein to the zymogen of human elastase 2 .

\subsection{Identification of the proCPA type involved in the two binary complexes}

In order to identify the type of the $44 \mathrm{kDa}$ proCPAs involved in the two binary complexes, the $\mathrm{N}$-terminal sequences of the isolate proCPAs have been determined and compared to those of proCPA from various species (table 1). These two sequences extending to residue 25 , were found to be strictly identical and to correspond to the $A_{1}$ type as shown by their higher homology to rat proCPA 1 than rat proCPA ${ }_{2}$ [14].

Comparisons with proCPAs from other species showed that human and porcine proCPAs are very homologous (for the first 25 residues a single substitution located in position 15 was observed) and also, that bovine and porcine proCPAs are likely to be of the $A_{1}$ type.

The N-terminal sequence of the CPA resulting from the tryptic activation of the proCPA involved in the proelastase 2 binary complex, has also been determined and compared to those of various CPAs (table 2). This sequence although uncompleted, further supports the fact that the human $44 \mathrm{kDa}$ proCPA belongs to the $\mathrm{A}_{1}$ type.

\subsection{Isolation and characterization of monomeric procarboxypeptidase $B$ \\ ProCPB was eluted from the gel filtration} chromatography of human pancreatic juice at the elution volume expected for a monomeric form [8]. Further purification of the protein by chromotagraphy on DE-Trisacryl at $\mathrm{pH} 8.0$ (fig.1) yielded two peaks.

The first major peak was shown to posses a high potential CPB activity and a very low potential CPA activity. Since CPB has been shown to exhibit a low activity towards synthetic CPA substrates, it cannot be ascertained that this peak contains proCPA traces. In the minor second peak the percent of proCPA potential activity relative to proCPB significantly increased. The CPA activity observed under this peak is likely to come from the minor $47 \mathrm{kDa}$ proCPA form, first identified in man by Scheele et al. [13], since only a $47 \mathrm{kDa}$ band was detected by SDS gel electrophoresis.

The occurrence of monomeric proCPB in the first

Table 3

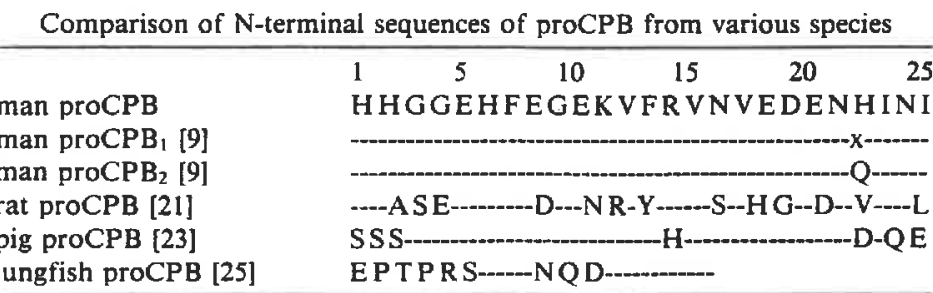

The human proCPB sequence is used as reference. $x$, unidentified residues 
peak was confirmed by $\mathrm{N}$-terminal sequence analysis. The sequence of the first 25 residues of the chain is presented in table 3 and compared to those of other proCPBs. It appears strictly identical to those of human proCPB $\mathrm{B}_{1}$ and proCPB ${ }_{2}$ described by Pascual et al. [9] except for residue 22 . In contrast to human proCPB which has a glutamine residue in position 22 , the presence of a histidine residue in this position in the monomeric proCPB allows us to postulate that this protein is of the $B_{1}$ type and confirms the occurrence of, at least, two forms of the enzyme in man.

During the $\mathrm{N}$-terminal sequence determination of proCPB, another sequence (20 amino acids) very similar to that of human $\mathrm{CPB}_{1}[26]$ was also detected (data not shown). The presence of the contaminant $\left(C P B_{1}\right.$ in the proCPB sample resulted from a noncontrolled activation of the zymogen. The type of the proCPB under the minor peak was not investigated.

\section{DISCUSSION}

In the human pancreatic juices studied, the major form of proCPA has a $M_{\mathrm{r}}$ of 44000 and occurs in two binary associations with functionally different proteins. One of them has been identified as a glycosylated truncated protease E [8], and in this paper, we report that the second proCPA complex involves proelastase 2 . This finding is the first evidence for the occurrence of a binary complex involving proCPA and proelastase 2 . Similar amounts of each binary complex were detected, suggesting that the truncated protease $\mathrm{E}$ and proelastase 2 compete for the same site on proCPA, with similar affinities.

The complexes were dissociated using DMMA, which induces electrostatic repulsion between the subunits. This strongly suggests that the binding of the truncated protease $\mathrm{E}$ and proelastase 2 to proCPA occurs through ion pairing as previously observed for the binding of truncated protease E to bovine proCPA [18].

Pascual et al. [9] described, in human pancreas, the presence of a single binary complex associating the 44 $\mathrm{kDa}$ proCPA to zymogen $\mathrm{E}$. the immediate precursor of protease E. However, it must not be ruled out that these discrepancies might result from genetic differences between individuals. Yet, the presence of a glycosylated truncated protease $\mathrm{E}$ in human pancreas has also been reported by Guy-Crotte et al. [27].

The presence of proCPA in association with other serine proteases in man and other species raises the question of the physiological significance of such complexes. In vitro, no dissociation has been observed during proteolytic activation of the human (data not shown) and bovine complexes [15]. Up to now, whether or not proteolytic activation induces in vivo the dissociation of these complexes remains unknown. It can be expected that these associations improve the protein digestion by physical effects such as stabilization of the proCPA as described for the bovine complex [4].

The $44 \mathrm{kDa}$ proCPA in the human binary complexes investigated in these studies was shown to belong to the $\mathrm{A}_{1}$ type. Seemingly the free or associated $44 \mathrm{kDa}$ proCPA forms isolated from human pancreas [9] are likely to be of the same $A_{1}$ type. This suggests that although different molecular secreted forms of secreted proCPA have been reported, human proCPA mainly occurs as a single $44 \mathrm{kDa}$ form belonging to the $\mathrm{A}_{1}$ type.

ProCPB was found secreted as a monomer with a $M_{\mathrm{r}}$ of 47000 . From $\mathrm{N}$-terminal sequence analysis, the major form of proCPB can be classified into the $B_{1}$ type since it contains an histidine residue in position 22 . Pascual et al. [9] reported a glutamine residue in the same position in human proCPB ${ }_{2}$. Except for this residue, the sequences of the first 25 amino acids of the $B_{1}$ and $B_{2}$ chains were identical, supporting the hypothesis of allelomorphism rather than gene duplication. The absence of a significant amount of proCPB in our analyzed human pancreatic juices is consistent with previous observations by Scheele et al. [13] and emphasizes the genetic differences between individuals.

Acknowledgements: We wish to acknowledge E. Foglizzo for skillful technical assistance. We are also greatly indebted to J. Bonicel for Nterminal sequence analyses.

\section{REFERENCES}

[1] Yamasaki, M., Brown, J.R., Cox, D.J., Greenshields, R.N., Wade, R.D. and Neurath, H. (1963) Biochemistry 2, 859-866.

[2] Kerfelec, B., Chapus, C. and Puigserver, A. (1985) Eur. J. Biochem. 151, 531-538.

[3] Peanasky, R.J., Gratecos, D., Baratti, J. and Rovery, M. (1969) Biochim. Biophys. Acta 181, 82-92.

[4] Kerfelec, B., Cambillau, C., Puigserver, A. and Chapus, C. (1986) Eur. J. Biochem. 157, 531-538.

[5] Cambillau, C., Kerfelec, B., Sciaky, M. and Chapus, C. (1988) FEBS Lett. 232, 91-95.

[6] Yoneda, T. (1980) Comp. Biochem. Physiol. 67B, 81-86.

[7] Kobayashi, R., Kobayashi, Y. and Hirs, C.H.W. (1978) J. Biol. Chem. 253, 5526-5530.

[8] Moulard, M., Kerfelec, B., Mallet, B. and Chapus, C. (1989) FEBS Lett. 250, 166-170.

[9] Pascual, R., Burgos, F.J., Salva, M., Soriano, F., Mendez, E. and Avilès, F.X. (1989) Eur. J. Biochem. 179, 609-616.

[10] Marchis-Mouren, G., Charles, M., Ben Abdeljlil, A. and Desnuelle, P. (1961) Biochim. Biophys. Acta 50, 186-188.

[11] Lacko, A.G. and Neurath, H. (1970) Biochemistry 9, $4680-4690$

[12] Reeck, G.R., Winter, W.P. and Neurath, H. (1970) Biochemistry 9, 1398-1403.

[13] Scheele, G., Bartelt, D. and Bieger, W. (1981) Gastroenterology $80,461-473$.

[14] Gardell, S.J., Craik, C.S., Clauser, E., Goldsmith, E.J., Stewart, C.B., Graf, M. and Rutter, W.J. (1988) J. Biol. Chem. 263, 17828-17836.

[15] Chapus, C., Kerfelec, B., Foglizzo, E. and Bonicel, J. (1987) Eur. J. Biochem. 166, 379-385.

[16] Folk, J.E., Piez, K.A., Caroll, W.R. and Gladner, J.A. (1960) J. Biol. Chem. 235, 2272-2277

[17] Largman, C., Broderick. J.W. and Geokas, M.C. (1976) Biochemistry 15, 2491-2500. 
[18] Kerfelec, B., Chapus, C. and Puigserver, A. (1984) Biochem. Biophys. Res. Commun. 121, 162-167.

[19] Laemmli, U.R. (1970) Nature (Lond.) 227, 680-685.

[20] Shirasu, Y., Yoshida. H., Matsuki, S., Takemura, K., Ikeda, N., Shimada, Y., Ozawa, T., Mikayama, T., Iijima, H., Ishida, A., Sato, Y., Tamai, Y., Tanaka, J. and Ikenaga, H. (1987) J. Biochem. 102, 1555-1563.

[21] Clauser, E., Gardell, S.J., Craik, C.S., MacDonald, R.J. and Rutter, W.J. (1988) J. Biol. Chem. 263, 17837-17845.

[22] Foglizzo, E., Bonicel, J., Kerfelec, B., Granon, S. and Chapus, C. (1988) Biochen. Biophys. Acta 954, 183-188.
[23] Avilès, F.X., Vendrell, J., Burgos, F.J., Sorjano, F. and Mendez, E. (1985) Biochem. Biophys. Res. Commun. 130, 97-103.

[24] Bradshaw, R.A., Ericsson, L.H., Walsh, R.A. and Neurath, H. (1969) Proc. Natl. Acad. Sci. USA 63, 1389-1394.

[25] Reeck, G.R. and Neurath, H. (1972) Biochemistry 11, 3947-3955.

[26] Guy-Crotte, O., Barthe, C., Basso, D., Fournet, B. and Figarella, C. (1988) Biochem. Biophys. Res. Commun. 156, 318-322. 